\title{
High school teacher perspectives and practices: Second language writing and language
}

\section{development}

\author{
Betsy Gilliland, University of Hawai'i Mānoa
}

This is an Accepted Manuscript of an article published by Taylor \& Francis in Language and Education on 19 January 2015, available online https://www.tandfonline.com/doi/full/10.1080/09500782.2014.1001398

\begin{abstract}
Teachers' understandings of second language learning influence their practices in the classroom. This paper analyzes interview and classroom data collected during a yearlong ethnographic study of two high school English language development classes to identify (1) what the teachers understood about second language (L2) development and L2 academic writing, and (2) to what extent these perspectives manifested in the teachers' writing instruction. Analyses suggest that the two teachers both felt language could be learned inductively through exposure to models and that writing instruction should focus on essay structure and correctness. Their teaching, however, was also constrained by accountability pressures from high stakes writing assessments. I argue that the teachers' approaches reflected a restrictive understanding not aligned with a situated perspective on language and writing development and therefore denied their multilingual students opportunities to learn academic language for writing.
\end{abstract}

Keywords: Writing, ESL, English language learners, academic language, language minority students, adolescents

\section{Introduction}

Multilingual ${ }^{1}$ adolescent writers constitute a substantial population in U.S. high schools

\footnotetext{
${ }^{1}$ Following May (2014), I use the term multilingual for recent immigrants, English language learners, and other linguistically diverse youth who speak more than one language, often using different languages in different social circumstances. Although the school classified most of the
} 
(Ortmeier-Hooper and Enright 2011), but few scholars have researched these students' experiences or their teachers' practices with writing. A few recent volumes (e.g. a 2011 special issue of Journal of Second Language Writing and de Oliveira and Silva 2013) have explored teachers' preparation programs for and students' experiences of writing instruction. Little research to date has considered the intersections of teachers' understandings of writing for academic purposes their teaching practices in high school second language classrooms. This paper analyzes interview and classroom data to identify (1) what the teachers understood about second language (L2) development and L2 academic writing, and (2) to what extent these perspectives manifested in the teachers' writing instruction. I argue that the teachers' approaches reflected a restrictive understanding not aligned with a situated perspective on language and writing development and therefore denied their multilingual students opportunities to learn academic language for writing.

\section{Teacher knowledge of language and writing}

Learning a new language and learning to write in that language are social practices. To use academic language proficiently, multilingual young people must learn how language functions in school contexts, particularly discipline- or activity-specific uses with grammatical and lexical constructions different from those of the learner's home (vernacular) language (Gee 2014). While academic language and writing are new for all students, multilingual students may be less familiar with the language of school and therefore need teacher assistance (Schleppegrell 2004). To learn the ways of using language and creating texts valued in school, learners must have opportunities to experience and practice academic language through developing their own socially situated identities as writers and language users within academic contexts, as well as the

students in the present study English learners (California's label for students not yet fluent English proficient), not all self-identified as such. 
metalanguage for talking about language (Gee 2014). Teachers can facilitate students' exploration of contexts where they use literacy (beyond the ESL classroom) and support discovery of language variation across discourse communities (Johns 1997).

Multilingual writers likewise have distinct learning needs as they develop academic literacy abilities in a new language. Like language learning, writing 'is an inherently social, transactional process that entails meditational activity involving writer, reader, text, and contexts for writing' (Ferris and Hedgcock 2014, 70). Many students can draw on knowledge they have developed in learning to write in their first language (Kobayashi and Rinnert 2013), but they also need more attention to discourses, linguistic structures, lexical expressions, and metalinguistic knowledge (Bunch 2013), since they may not have a intuitive sense of what 'sounds right' (Reid 1998). Thus teaching multilingual writers requires a balance between language and rhetorical and structural issues.

From these perspectives, neither language nor writing can be taught or learned in isolation from specific social uses of language and writing (Street 2012). Not all teachers, however, see their work within a larger social context. A study skills approach perceives the role of the writing teacher to be one of giving students a set of universally applicable tools for writing in any context (Lea and Street 1998). In this autonomous view of literacy, a unitary literacy capacity can transfer to all academic and social settings (Ivanic 2004). In contrast, teachers who hold an academic literacies perspective understand the importance of social and ideological context in determining how language is used in writing for a particular purpose (Street 2012).

Teachers' limited understanding of second language development can negatively influence their approaches to teaching multilingual learners. Demographics in U.S. schools now mean that mainstream no longer indexes white native speakers of standard varieties of Englishtoday, the new mainstream (Enright 2011) is actually multiethnic and multilingual, so all 
teachers are teachers of multilingual learners. Both English-as-a-second-language (ESL) teachers and mainstream content teachers, however, may hold misconceptions about language learning and bilingualism in the classroom and at home (Pettit 2011; Gebhard and Harman 2011; Reeves 2006). Some equate language with vocabulary and focus language instruction on word-level learning, practices that prevent students from learning other language functions necessary for learning the content of the curriculum (Richardson Bruna, Vann, and Perales Escudero 2007). Others believe that language can be learned implicitly through exposure, such as from having a word wall in the classroom without explicit emphasis on new linguistic features (Webster and Valeo 2011), or from instructional practices that work with fluent English speakers (Harper and de Jong 2004; Clair 1995). Many teachers hold deficit views of their multilingual students, seeing their poor performances on standardized tests as evidence of limited intellectual capacity (Rolstad 2014).

Teacher education policy generally ignores L2 development (Bunch 2013; Fleming, Bangou, and Fellus 2011; Paterson 2010) or presents a reductive interpretation of Krashen's work, emphasizing input (reading) and output (writing) but not language (Gebhard and Harman 2011). Few states require mainstream teachers to take courses on working with multilingual learners, and none require coursework in linguistics (Stevens 2008; Samson and Collins 2012). States like California (at the time of this study) ${ }^{2}$, in fact, have no specialized certification for teachers of English learners but instead provide all teachers with some instruction about multilingual learners and therefore consider them prepared to teach students learning English. Even teachers with specialized preparation may have factual knowledge about language or linguistics, but not an understanding of how language functions in the production of disciplinary texts (Bunch 2013; Fleming, Bangou, and Fellus 2011). A case study of one California high

\footnotetext{
${ }^{2}$ California has since approved a "World Language: English Language Development” credential.
} 
school English language development (ELD) teacher revealed that even with a degree in TESOL, she felt uncertain how best to help her multilingual students learn academic English (Malsbary and Appelgate forthcoming).

Teachers' understandings of the purpose and practices of second language writing can also impact their teaching. Their instruction may limit multilingual students' understanding of writing to an exercise done for the teacher, rather than as communicating ideas to an audience (Ortmeier-Hooper 2013). Others may not clarify for or share with their students their criteria for good writing (Beck 2006). The teacher in Beck's study, for example, provided supports like sentence frames, but only some students recognized his expectations for their writing. Larsen's (2013) survey of secondary ESL teachers found that a majority felt unprepared for teaching L2 writing, although most taught writing as a core content area of their classes. Even teachers with theoretically sound understandings of writing pedagogy may still enact less beneficial practices in their actual teaching. For example, Yi (2013) identified two pre-service ESL teachers who incorporated innovative approaches into their teaching of writing but nevertheless used writing primarily for assessment purposes. L2 writing instruction in secondary schools is further influenced by education policy that requires annual standardized tests, including on-demand writing assessments (Harklau 2011). Because these exams carry high stakes for both schools and students, writing instruction in secondary classrooms with multilingual students and other struggling writers often focuses on formulaic texts to fit official rubrics (Enright \& Gilliland, 2011).

Taken together, the literature reviewed here demonstrates multiple ways in which teachers' knowledge base influences their practices in teaching language and writing to multilingual learners. Few studies, however, have addressed implications of teacher understandings about language and writing in secondary school. The present study analyzes two 
high school teachers teaching academic writing to multilingual students designated by the school district as English learners.

\section{Methodology}

Willowdale High School (WHS) ${ }^{3}$, the site of this study, was a comprehensive high school serving 1503 students in grades 9 to 12 . WHS demographics $\left(55 \%\right.$ Hispanic $^{4}$ and $40 \%$ White non Hispanic students from many socioeconomic backgrounds; $20 \%$ of all students were classified as English learners and another 20\% spoke a language other than English at home) paralleled statewide averages for California high schools. This paper analyzes a subset of data collected during an ethnographic study at WHS involving during the 2009-10 academic year (Gilliland, 2012).

Data were collected in two sections of an advanced English language development (ELD) class, 'Transitions to English.' A yearlong two-period class intended to prepare students designated by the school district as English learners for mainstream English the following year, Transitions covered the California ninth grade English language arts (ELA) standards, which focused on literary fiction and poetry analysis, as well as grammar topics such as parts of speech and punctuation. Course requirements also included five district-mandated ninth grade Benchmark Assignments (BAs), multi-draft essays with prompts like those on the high school exit exam. District rubrics for grading the BAs emphasized essay structure and linguistic correctness over argument (Enright \& Gilliland, 2011 analyzes the effects of the BA policy on multilingual writers in mainstream classrooms). Therefore, while officially listed as an ELD course, Transitions followed a curriculum developed for mainstream ELA courses with few official adaptations for multilingual students still learning academic English.

\footnotetext{
${ }^{3}$ All names of participants and places are pseudonyms.

${ }^{4}$ California's use of 'Hispanic' in demographics refers to ethnicity, not language.
} 


\section{Data sources}

Data sources include interviews and audio recordings of class sessions focused on writing. Field notes documented teachers' statements about language, writing, and the writing process, references to texts used in assignments, and instruction on writing. Both teachers were interviewed twice using semi-structured protocols of open-ended questions based on the research goals, observations, and initial analysis of field notes. Some interview questions asked specifically for their perspectives about language and writing.

One section of Transitions, taught by Evelyn Chou, enrolled 15 students in $10^{\text {th }}$ to $12^{\text {th }}$ grades. The other section of Transitions, taught by Shawn Brown, enrolled 32 ninth-grade students. The students in both classes were primarily Spanish speakers still classified by the school district as English learners, but with a range of immigration histories: some had moved to the United States only a few years earlier, others had immigrated as young children, while still others had been born in California.

The two teachers were as well prepared for teaching multilingual students as California policy required. Ms. Chou had been teaching middle and high school ELA classes for 12 years and had an undergraduate minor in TESOL with an English Education major. She said her coursework had included 'linguistics, sociolinguistics, [and] how to teach ESL in foreign countries' but nothing on teaching immigrant youth. Mr. Brown had been teaching ninth grade ELA for six years. His California teaching credential program, a post-baccalaureate secondary ELA credential, included the CLAD (Crosscultural, Language, and Academic Development) endorsement required by state policy, which he said had emphasized multicultural education more than language development. California did not license teachers for ELD at the time of this study; both teachers were certified to teach ELA. 
Both teachers said they had participated in some professional development related to teaching writing, although these training sessions introduced commercial writing curricula rather than a general understanding of writing instruction. During the year of this study, both teachers were participating in trainings related to the $\mathrm{WRITE}^{5}$ program that the school district expected them to use on top of the BAs in Transitions. Ms. Chou explained that these trainings mainly focused on practicing activities from the worksheets provided in the program binders and scoring student essays using the WRITE program rubrics.

\section{Data analysis}

The goal for analysis was to identify individual teachers' understandings of academic language and L2 writing, as revealed through interviews and observations of their teaching practices, viewed through an academic literacies lens (Street 2012). Following Strauss's (1987) constant comparison method, data were analyzed through open coding (considering themes in each piece of data), axial coding (labeling themes and looking for core concepts), and selective coding (identifying relationships among categories and linking them to core concepts) to understand how participants made sense of observed interactions. Segments of field notes and audio transcripts were selected for detailed meaning reconstruction based on the intensity of talk around writing or language (Carspecken 1996). Analyses suggested that the teachers held distinct views on how language was learned, but could not elaborate clearly how students learned L2 writing.

\section{Findings}

Findings revealed that both teachers had flawed understanding of both L2 development and L2 writing instruction. Furthermore, combined with perceived pressure from accountability

\footnotetext{
${ }^{5}$ Writing Reform and Innovation for Teaching Excellence (http://www.writeinstitute.net/) is a professional development and curriculum program focused on English learners.
} 
measures, these understandings meant that their instructional practices were not aligned with current thinking on either language learning or second language writing. The first section illustrates what the teachers said and did with respect to teaching academic English; the second section addresses their understandings and practices in second language writing.

\section{Teaching language and language learners}

Although both teachers had studied something about language in their credentialing programs, neither presented a theoretically informed understanding of second language development nor recognized the Transitions students as language learners. This section suggests that the two teachers' flawed understanding limited what they taught their students about language.

\section{Language is learned inductively}

Both teachers said language learning could be accomplished inductively through reading and repeated exposure to written texts. Mr. Brown explained in an interview that he expected students would passively develop a facility with academic language through regular use of sentence starters he provided students for each assignment:

Through the use of the sentence starters, the frames, they kind of start to internalize that and you see that when they're doing informal short answer stuff. They start to use some of those instead of--like they answer with a complete answer.

This statement reflects Mr. Brown's understanding of students' improved language being reflected less in the originality of their writing as in their ability to employ the complete sentence frame independently.

Neither teacher mentioned explicitly talking about language with their classes. Instead, when asked what was important for their students' language development, both spoke more about structural aspects of writing. Ms. Chou focused on thesis support, de-emphasizing the importance of language:

Author: What principles do you believe are important for language learning? 
Chou: Just being able to, again, write a thesis statement, support a thesis statement. That's probably the biggest skill that they'll need, as far as writing goes, as far as language. You don't necessarily have to be able to articulate it beautifully to get your point across, but if you have the logic and the thought behind it, then you can.

This concern with thesis statements suggests she felt that students could learn academic language inductively, through practicing formulaic and universal writing skills (Lea and Street 1998). While acknowledging the developmental nature of second language writing, Ms. Chou's statement reflects a limited understanding of the Transitions students' ongoing need to learn how to use language (contextually appropriate vocabulary, syntax, and register) in order to write the thesis statements she saw as fundamental to academic writing (Gee 2014).

When I asked Mr. Brown the same question, he did not explicitly state a clear understanding of language development, either, focusing instead on how he perceived the students to need more time and structure (in a way, how to do school) rather than instruction in the language of school:

So what takes the [mainstream classes] one hour to do with [the textbook], it'll take these guys two hours. [...] These guys just need more help. They need more explicit guidance. If I'm asking them to do something, I have to show them exactly and tell them exactly what I'm looking for. Whereas with some of the other classes I can say OK, this is what I need you to do. I guess my principle would be more scaffolding, more help in general. $[\ldots$ T]hey need those graphic organizers. I mean those are effective for all students, but language learners need to kind of see that kind of pattern, I think.

In this explanation, Mr. Brown demonstrated an awareness of the Transitions students as still learning academic English, recognizing that they needed more time and support in their linguistic work. Graphic organizers and models do provide support, but his approach did not go far enough to facilitate students' learning to use language independently. By emphasizing his role in 
'tell[ing] them exactly,' Mr. Brown suggested that he doubted the students' ability to write on their own. These understandings were reflected in the ways both teachers talked about language with their students as data from the classroom talk illustrates.

\section{Language is structure and style}

While the Transitions classes were officially English Language Development classes, language development was not a focus of teaching. Both teachers' practices highlighted discrete elements of language, without connecting to the students' more global needs to learn how to use language across disciplines for varied and multiple purposes (Bunch 2013). Though this concern is true for all students, multilingual learners face additional challenges when teacher practices ignore their unique learning needs (Harper and de Jong 2004).

Because he felt the students could learn inductively from repeated use of models, Mr. Brown employed academic language sentence frames. For the persuasive essay, he wrote sentence frames on the board as the students added quotations to graphic organizers. I recorded in my field notes:

Mr. Brown works with the group doing legalization of marijuana. As he explains to them how to begin a sentence citing information from a source, he writes on the board:

According to Legalizationofmarijuana.com,

This quote shows...

According to Mr. Brown's interpretation of the BA rubric, evidence had to be in the form of a direct quotation, so the sentence frame for the subsequent explanation box was consistently 'This quote shows.' This structure appeared in students' writing almost every time a student used a quotation, even though the subsequent text was usually more paraphrase than analysis. Students' writing frequently contained exact transcriptions of Mr. Brown's sentence frames, followed by sometimes-incoherent phrases attempting to connect the quotation to a thesis statement. Mr. 
Brown's use of sentence frames without instruction into their functions maintained a focus on form over message, reducing academic language to a surface-level concern.

Beyond their focus on language as formulaic structures, both teachers' practices revealed their own limited capacity to articulate for students how to select appropriate language for writing. Sometimes, the teachers' approaches manifested in the terminology they used to discuss semantic and syntactic choices. Mr. Brown focused on language as style, invoking literary voice (Ramanathan and Atkinson 1999) in a way that reflected the word-level focus valued in the rubric and textbook:

Brown: If I'm writing an essay about trying to persuade people to stop smoking, or to quit smoking cigarettes, I'm not going to say, my opinion statement wouldn't be, 'People shouldn't smoke cigarettes because it's bad for their health.' That's not strong enough. It's not forceful enough. Boy: But it's true, right?

Brown: It is true. But I would say, I would use something like, um, 'It is imperative that people who smoke stop immediately.' Do you see the difference between that and 'People should stop smoking'? Boy: It's big words that we don't know.

Brown: It's not about big words. It's about the type of words. It's about being forceful, using forceful language.

Mr. Brown had an idea in his mind of the difference between weak and strong language, but he could not explain it to the students. As language learners, many were aware that they did not know words such as imperative, but did not have the terminology to make sense of Mr. Brown's explanation. Voice, furthermore, invokes cultural and linguistic values that are often unfamiliar to multilingual students (Ramanathan and Atkinson 1999). 
Like Mr. Brown, Ms. Chou rarely explained how students could learn to use language, but she expected that they use correct forms and word choice in their final drafts. Although her students did frequent grammar workbook exercises on verb tense errors or apostrophes, I never observed explicit instruction about grammar or other aspects of language. Ms. Chou recognized, however, that the students had limited control over the linguistic forms they used in their writing and required students to bring their essays to her for approval of both essay structure and language conventions before drafting their essays. She explained to one student:

I wanna see a thesis statement, and I want to see an outline before you actually even start writing. I wanna make sure it's correct! And that your reasons are good before I actually let you write. Because if not, then you're not gonna have a strong enough paper. To do well.

In this statement, Ms. Chou set clear boundaries for what students could do on their own and for where they should rely on the teacher. They could not trust their own knowledge of the correctness of their language use but instead needed to get teacher approval before continuing with their projects. In framing this statement in a concern for students' final performance on the assignment, Ms. Chou also established writing as something that students could only do with teacher permission — and that the brainstorming and planning they had already done did not count as 'writing.' These teacher-controlled procedures established a classroom understanding that academic writing was governed by strict formulas and rules even beyond the patterns and organizational structures their teachers had explicitly shared. Her final phrase, 'To do well,' acknowledges the actual reason for writing in Transitions - the BA assessment. As the next section examines, the teachers' classroom practices were further constrained by the omnipresent BAs and the high stakes placed on students' performance. 


\section{Teaching L2 writing}

In response to interview questions asking specifically about teaching writing in their Transitions classes, neither teacher indicated awareness of theoretical or pedagogical differences between teaching L1 and L2 writing. Like their approaches to teaching language, their teaching of L2 writing indicated flawed understandings of the social nature of writing and current best practices, although both reflected that they would have taught writing differently had they not felt pressure from the district to complete the Benchmark Assignments (BAs) and use required curriculum.

\section{Literacy and pedagogy}

The teachers described their views on teaching writing in terms of both what they did in their instructional practices and what they expected students to be able to do. While they shared an understanding of literacy as universally applicable, their pedagogical approaches differed. With respect to writing instruction, Ms. Chou told me when I asked what was most important in teaching writing: 'Support their thesis statements. Support what they say logically. I think that carries across all disciplines if they can do that.' She believed that these fundamental structural skills would transfer to any writing students would need to do in their future academic pursuits, a reflection of the autonomous view of literacy (Ivanic 2004).

Ms. Chou held that students could learn to write by putting their existing ideas into words, without much direct instruction from her. She wanted to guide students' development of their own understanding by scaffolding their critical thinking:

I try for open-ended [comments] unless I see a major flaw. I try to ask questions more than make statements. So if a body paragraph doesn't seem to fit with the thesis statement, I will on the side say, 'How does this support your thesis?' Cause I want them to think about it. I don't want necessarily to just give them everything. This approach to feedback suggests Ms. Chou saw herself as a guide rather than a director of what students should write. In the classroom, she waited for students to ask for help rather than 
providing directives. Having taught high school writing for a decade, she said she had found this approach to work well with her mainstream students, but analyses show that it limited the multilingual Transitions students' learning. As other data from this study reveal, Ms. Chou's questioning approach left multilingual students unsure how to choose language to serve a specific purpose for writing (Gilliland, 2014).

Like Ms. Chou, Mr. Brown saw academic writing as something that could be taught without consideration of the larger contextual factors of the classroom or students' linguistic resources. In contrast with Ms. Chou, however, he believed in the importance of direct instruction, particularly for students unfamiliar with academic writing. Attributing his views to a credential program that stressed teaching to the standards, he told me: 'Explicit writing instruction is crucial. How to format, what types of info you need to include in specific types of writing. How to create logical flow of ideas. Things like that, they get lost, I think.' In presenting academic writing as a list of features measured on the Benchmark Assignment rubrics, Mr. Brown's view reflected the prevailing attitudes in the district, a study skills approach (Lea and Street 1998) focused on the BAs as formative assessments indicating where students needed remediation before taking the high school exit exam. He described how he introduced a new BA to his class:

Brown: I'll give them some initial instruction: 'This is the genre, these are the elements of the genre.' Then I'll give them the graphic organizers to help them start to organize. From there we build to the draft and we always do the first draft written in class together. I circulate and if they get a paragraph down, I'll skim through it and mark, say, fix this, add this, you're missing this. Things like that. And I try to do that with all the students for their first draft. [...] And so the comments, the feedback comes during the drafting process so that when they're ready to do their final, they've gotten the most feedback as possible. 
Author: How do you know whether that works for your students?

Brown: When I look at their final product and I can use the rubric to say OK, you clearly, you can look at the draft and say this is what the suggestions, look at the rubric and the final draft, did they take those suggestions to heart and fix those things.

Mr. Brown's feedback approach acknowledged the central role of the BA rubric in shaping his advice to students: he knew what they must have (or not have) in their essays in order to pass, so he focused directive comments on their early drafts to points where they could raise their scores. As he described his process, his feedback did not consider the students as L2 learners, but rather as remedial writers lacking necessary elements in their texts. He did not waste time asking what they wanted to say, but instead told them what to change. He evaluated his success by the alignment between the rubric and students' following his directions.

\section{Writing as formulaic structure}

While the two Transitions teachers expressed differing views on writing instruction, faced with the Benchmark Assignment requirements, both focused on essay structure over development of ideas or language. The teachers presented the persuasive research essay as a genre that should be fully planned prior to doing research, whose main purpose was to find facts that supported an existing opinion.

Ms. Chou told her Transitions students that the main goal of a persuasive essay was 'to convince someone you're right' about 'some kind of topic that you have an opinion about.' In order to support that opinion, the writer must start with an issue about which she feels strongly and already has a 'solid opinion': 'Yes or no. You have to have a solid opinion. You can't be in the middle.' Both teachers expected students to finalize their opinions and supporting reasons prior to doing research, and then to find texts to support those reasons. Students missing appropriate facts had to find different published information rather than revise their arguments. 
In following these strict formulas for writing, students learned that they had to have their ideas ready before drafting their essays.

While severely restricting what students learned about the genre of persuasive writing, this approach did keep classroom practices focused on efficient progress through the BA toward a serviceable final product. With limited time in the school year to produce passing drafts of five different BA essays, Mr. Brown explained in an interview that the teachers could not take the time to guide students through an inquiry process of generating questions and searching for nuanced answers. The product-based focus meant that both teachers created rigid structures into which students had to fit their writing.

The teachers' emphasis on the importance of structure as a means of addressing accountability requirements was evident in the way they enacted the writing process in their classes. Over seven years teaching from the same textbook, Mr. Brown had developed extensive support packets for each BA, covering prewriting to paragraph writing. For the persuasive essay, for example, the 9-page packet outlined the required format and content of the essay in a series of graphic organizer grids.

Because of the minimal guidelines in the official BA prompt, Mr. Brown had written a descriptive text reflecting his interpretation of the persuasive essay assignment and the formulaic nature of academic writing. Introducing the assignment to the Transitions class, he directed students to the requirements:

OK, let's look at some of the requirements. The requirements. Minimum, five paragraphs. This is a five-paragraph essay. We've got an introduction; we've got three body paragraphs, and a conclusion. For your opinion statement, you're gonna have to come up with three reasons why you think that. 'This is my opinion because of this reason, this reason, and this reason.' Each reason is a body paragraph. Exactly. 
This example highlights Mr. Brown's emphasis on close adherence to the Benchmark Assignment rubric. Although the rubric did not specifically state the number of paragraphs (as the packet did), it did have a category called 'Content: Persuasive Appeals,' which named three types of appeals - a concrete number that lent itself to Brown's division of the essay into three body paragraphs, each focused on a different type of appeal. The rubric did specify that the writer should use at least two sources; Brown translated this expectation into a requirement of two evidence citations per paragraph. His 'exactly' at the end of the description emphasizes the focus on meeting these structural requirements.

Ms. Chou's writing instruction demonstrated a similar emphasis on structure over other traits. While she did not provide students with a worksheet, she did expect students prior to drafting any paragraphs to have already determined their thesis, three specific reasons, and supporting evidence for each of those points in their essay. For each student, Ms. Chou handwrote a formal outline structure on a blank piece of paper. Like Mr. Brown's packets, Ms. Chou's outline directed students to fit their ideas into a traditional five-paragraph essay format. The official rubric strongly suggested a five-paragraph structure for most of the BA essays. The writing process in both classes reflected a dependence on the initial structure to the extent that students did little revision after filling in the graphic organizer or outline. On receiving teacher approval of their worksheet text, they copied it onto a blank piece of paper or into a word processing document. Their only revisions were at the word level.

The teachers were aware of the BA policy's influence on their writing instruction, but they justified the practices by pointing to their success at getting their students through the assignments. When I asked him to evaluate the success of his approach to teaching writing, Mr. Brown explained his reasoning for the extensive scaffolding: 
Brown: We're data heavy, and I can look at the numbers of referrals from my class to the Learning Center $^{6}$ versus referrals from other teachers, and I think, I have less referrals because of these kind of things.

Author: So you catch it before the draft is due.

Brown: Exactly, proactive vs. reactive.

This concise summary indicates Mr. Brown's awareness of the role of assessment and the district's focus on product rather than process. To him, being 'proactive' meant that the students were able to get the correct answer the first time around. The authorities judged his success as a teacher by the number of students referred to the Learning Center (those who were not able to achieve a passing score the first time around). As in many California school districts, this 'data heavy' approach only considered statistics as data. Qualitative concepts like whether students understood what they were doing or could write independently did not factor into the district's consideration of successful teaching. By viewing the multilingual students as needing time, structure, and correction, but not language instruction, in order to meet district expectations, the teachers' writing instruction missed many opportunities to facilitate students' academic literacies development.

\section{Discussion}

Findings from this study suggest that in making decisions about their classroom practices, the two Transitions teachers' views about writing and academic language development guided and were influenced by their interpretations of curricular requirements and their students' learning needs. Though both teachers provided explicit instruction in the structure of academic writing assignments, their teaching and interview responses indicated that they held much less clear understandings of teaching language or teaching students considered language learners.

\footnotetext{
${ }^{6}$ Students who failed a Benchmark Assignment revised their essays with a tutor at the campus Learning Center during school hours.
} 
Their instructional practices portrayed writing as procedures (such as placing existing ideas into fixed formulas) rather than as critical thinking (such as exploring new ideas). School district policies mandating standardized assessments like the Benchmark Assignments (BAs) privileged these surface features — doing school — over teaching students how to select appropriate language or how to approach similar writing on their own-learning the language of schooling (Schleppegrell 2004).

I do not wish to be critical of Mr. Brown and Ms. Chou as teachers. Indeed, both were dedicated professionals who ensured their multilingual Transitions students had opportunities to pass the Benchmark Assignments and progress into mainstream English classes. The Transitions classes, however, represented a unique case where mainstream curriculum policy intersected with grouping students by assessed language proficiency. In other WHS classes for students designated as English learners, teachers used curriculum specifically developed for language learners. In mainstream classes, most students were no longer designated as ELs. Requiring the 9th grade curriculum and the BAs in Transitions, therefore, meant that Transitions students' coursework aligned with what their mainstreamed peers did, rather than focusing on their language learning needs. With no standards, course goals, or assessments for multilingual learners, however, in Transitions, the BAs became a product, with rubrics written for native speakers, and the teachers did not focus on writing processes in terms of L2 writing best practices. [Gilliland (forthcoming) discusses the Transitions curriculum in more detail.] State teacher licensure regulations compounded the policy problems. In California, no additional preparation was required for teaching ELD or other classes for multilingual learners. Therefore, in the eyes of the state, all teachers were qualified to teach students designated as English learners - but this also meant that no teachers were required to have specialized knowledge for teaching these students. Both teachers in this study admitted that their credential 
programs had emphasized either facts about linguistics (unrelated to contexts of immigrant language learners in schools) or multicultural education (without consideration of language learning), and neither had taken coursework focused on teaching L2 writing.

Both teachers held autonomous views of literacy (Ivanic 2004). Their support, which both said worked well with students in their mainstream classes, neglected the linguistic learning needs of the multilingual students in their classes; what is considered 'just best practices' in mainstream classrooms often fails to address multilingual learners' need to learn how and why

they should use particular structures in academic writing (Street 2012; Harper and de Jong 2004). Supporting disciplinary academic literacy requires teachers to understand language use in specific contexts, especially for writing (Bunch 2013). In these classes, however, language was a surface-level concern that reflected both teachers' focus on the disciplinary norms of secondary school English language arts (particularly mastery of the BAs) rather than language for communication.

\section{Conclusion}

Research continues to show that high school teachers receive little to no preparation for teaching either language learners (Stevens 2008; Ardila-Rey 2008) or second language writing (Larsen 2013). This study suggests that even teachers who have had some coursework in teaching language learners teach from limited understandings of second language learning and writing development, compounded by policy requirements. As the new mainstream (Enright 2011) becomes the norm, teacher education must focus more on preparing all teachers to teach multilingual learners, because even if they do not have a full class of students designated as ELs, they will increasingly have students needing language support. Professional development should help teachers understand academic language development and writing instruction to give multilingual students access to curriculum and help them think about writing and language for 
future uses (see for example recommendations in Gibbons 2014; Ortmeier-Hooper 2013).

\section{Funding}

This research was supported in part by the PEO Scholars Award and the UC-ACCORD

Dissertation Fellowship. 


\section{References}

Ardila-Rey, Alicia. 2008. "Language, Culture, Policy, and Standards in Teacher Preparation." In Language, Culture, and Community in Teacher Education, edited by María Estela Brisk, 331-51. New York: Lawrence Erlbaum Associates.

Beck, Sarah W. 2006. "Subjectivity and Intersubjectivity in the Teaching and Learning of Writing." Research in the Teaching of English 40 (4):413-60.

Bunch, George Clay. 2013. "Pedagogical Language Knowledge: Preparing Mainstream Teachers for English Learners in the New Standards Era." Review of Research in Education 37 (1):298-341. doi: 10.3102/0091732x12461772.

Carspecken, Phil Francis. 1996. Critical Ethnography in Educational Research: A Theoretical and Practical Guide. New York: Routledge.

Clair, Nancy. 1995. "Mainstream Classroom Teachers and ESL Students." TESOL Quarterly 29 (1):189-96. doi: 10.2307/3587817.

de Oliveira, Luciana C., and Tony Silva, eds. 2013. L2 Writing in Secondary Classrooms: Students' Experiences, Academic Issues, and Teacher Education. New York: Routledge.

Enright, Kerry Anne. 2011. "Language and Literacy for a New Mainstream." American Educational Research Journal 48 (1):80-118. doi: 10.3102/0002831210368989

Enright, Kerry Anne, and Betsy Gilliland. 2011. "Multilingual Writing in an Age of Accountability: From Policy to Practice in U.S. High School Classrooms." Journal of Second Language Writing 20 (3):182-95. doi: 10.1016/j.jslw.2011.05.006

Ferris, Dana R., and John S. Hedgcock. 2014. Teaching L2 Composition: Purpose, Process, and Practice. Third ed. New York: Routledge.

Fleming, Douglas, Francis Bangou, and Osnat Fellus. 2011. "ESL Teacher-Candidates' Beliefs About Language." TESL Canada Journal/Revue TESL du Canada 29 (1):39-56. 
Gebhard, Meg, and Ruth Harman. 2011. "Reconsidering Genre Theory in K-12 Schools: A Response to School Reforms in the United States." Journal of Second Language Writing 20 (1):45-55. doi: 10.1016/j.jslw.2010.12.007.

Gee, James Paul. 2014. "Decontextualized Language: A Problem, Not a Solution." International Multilingual Research Journal 8 (1):9-23. doi: 10.1080/19313152.2014.852424.

Gibbons, Pauline. 2014. Scaffolding Language, Scaffolding Learning. Portsmouth, NH: Heinemann.

Gilliland, Betsy. 2014. "Academic Language Socialization in High School Writing Conferences." Canadian Modern Language Review/La Revue canadienne des langues vivantes 70 (3): 303-30. doi: 10.3138/cmlr.1753

Gilliland, Betsy. Forthcoming. "Opportunity Gaps: Curricular Discontinuities across ESL, Mainstream, and College English." Linguistically Diverse Immigrant and Resident Writers: Transitions from High School to College, edited by Ortmeier-Hooper, Christina and Todd Ruecker. New York: Routledge.

Gilliland, Elizabeth Alice. "Talking About Writing: Culturally and Linguistically Diverse Adolescents' Socialization into Academic Literacy." Dissertation. University of California, Davis, 2012.

Harklau, Linda. 2011. "Commentary: Adolescent L2 Writing Research as an Emerging Field." Journal of Second Language Writing 20 (3):227-30. doi: 10.1016/j.jslw.2011.05.003. Harper, Candace, and Ester de Jong. 2004. "Misconceptions About Teaching English-Language Learners." Journal of Adolescent \& Adult Literacy 48 (2):152-62. doi: 10.1598/jaal.48.2.6.

Ivanic, Roz. 2004. "Discourses of Writing and Learning to Write." Language and Education 18 (3):220-45. doi: 10.1080/09500780408666877. 
Johns, Ann M. 1997. Text, Role and Context: Developing Academic Literacies: Cambridge University Press.

Kobayashi, Hiroe, and Carol Rinnert. 2013. "Second Language Writing: Is It a Separate Entity?" Journal of Second Language Writing 22 (4):442-3. doi: 10.1016/j.jslw.2013.08.008.

Larsen, Ditlev. 2013. "Focus on Pre-Service Preparation for ESL Writing Instruction." In L2 Writing in Secondary Classrooms, edited by Luciana C. de Oliveira and Tony Silva, 11932. New York: Routledge.

Lea, Mary R., and Brian V. Street. 1998. "Student Writing in Higher Education: An Academic Literacies Approach." Studies in Higher Education 23 (2):157-72.

Malsbary, Christine Brigid, and Mollie H. Appelgate. forthcoming. "Working Downstream: A Beginning EL Teacher Negotiating Policy and Practice." Language Policy. doi: 10.1007/s10993-014-9347-6.

May, Stephen, ed. 2014. The Multilingual Turn: Implications for SLA, TESOL and Bilingual Education. New York: Routledge.

Ortmeier-Hooper, Christina. 2013. The ELL Writer: Moving Beyond Basics in the Secondary Classroom. New York: Teachers College Press.

Ortmeier-Hooper, Christina, and Kerry Anne Enright. 2011. "Mapping New Territory: Toward an Understanding of Adolescent L2 Writers and Writing in Us Contexts." Journal of Second Language Writing 20 (3):167-81. doi: 10.1016/j.jslw.2011.05.002.

Paterson, Laura Louise. 2010. "Grammar and the English National Curriculum." Language \& Education: An International Journal 24 (6):473-84. doi:

10.1080/09500782.2010.495782. 
Pettit, Stacie Kae. 2011. "Teachers' Beliefs About English Language Learners in the Mainstream Classroom: A Review of the Literature." International Multilingual Research Journal 5 (2):123-47. doi: 10.1080/19313152.2011.594357.

Ramanathan, Vai, and Dwight Atkinson. 1999. "Individualism, Academic Writing, and ESL Writers." Journal of Second Language Writing 8 (1):45-75. doi: 10.1016/S10603743(99)80112-X.

Reeves, Jenelle R. 2006. "Secondary Teacher Attitudes toward Including English-Language Learners in Mainstream Classrooms." Journal of Educational Research 99 (3):131-42. Reid, Joy. 1998. "'Eye' Learners and 'Ear' Learners: Identifying the Language Needs of International Student and U.S. Resident Writers." In Grammar in the Composition Classroom, edited by Patricia Byrd and Joy Reid, 3-17. New York: Heinle.

Richardson Bruna, Katherine, Roberta Vann, and Moisés Perales Escudero. 2007. "What's Language Got to Do with It?: A Case Study of Academic Language Instruction in a High School "English Learner Science” Class." Journal of English for Academic Purposes 6 (1):36-54. doi: 10.1016/j.jeap.2006.11.006.

Rolstad, Kellie. 2014. "Rethinking Language at School." International Multilingual Research Journal 8 (1):1-8. doi: 10.1080/19313152.2014.852423.

Samson, Jennifer F., and Brian A. Collins. 2012. "Preparing All Teachers to Meet the Needs of English Language Learners." In. Washington, D.C.: Center for American Progress. Schleppegrell, Mary. 2004. The Language of Schooling. Mahwah, NJ: Lawrence Erlbaum. Stevens, Lisa Patel. 2008. "Educational Policy and Linguistic Diversity." In Language, Culture, and Community in Teacher Education, edited by María Estela Brisk, 315-30. New York: Lawrence Erlbaum Associates. 
Strauss, Anselm L. 1987. Qualitative Analysis for Social Scientists. New York: Cambridge University Press.

Street, Brian. 2012. "New Literacy Studies." In Language, Ethnography, and Education: Bridging New Literacy Studies and Bourdieu, edited by Michael Grenfell, David Bloome, Cheryl Hardy, Kate Pahl, Jennifer Rowsell and Brian Street, 27-49. New York:

Routledge.

Webster, Nina Lee, and Angela Valeo. 2011. "Teacher Preparedness for a Changing Demographic of Language Learners." TESL Canada Journal 28 (2):105-28.

Yi, Youngjoo. 2013. "ESOL Teachers as Writing Teachers: From the Voices of High School Pre-Service Teachers." In L2 Writing in Secondary Classrooms, edited by Luciana C. de Oliveira and Tony Silva, 133-48. New York: Routledge. 